\title{
TEMPORAL CHANGES IN MIGRATORY FISH BODY SIZE IN A NEOTROPICAL FLOODPLAIN
}

\author{
Taise Miranda Lopes ${ }^{1 *}$, Oscar Peláez ${ }^{1}$, Rosa Maria Dias ${ }^{1}$, Anielly Galego de Oliveira ${ }^{1}$, \\ Rafaela Giacomel Rauber ${ }^{1}$, Luiz Carlos Gomes ${ }^{1,2}$ \& Angelo Antonio Agostinho ${ }^{1,2}$

\begin{abstract}
${ }^{1}$ Universidade Estadual de Maringá, Programa de Pós-Graduação em Ecologia de Ambientes Aquáticos Continentais, Av. Colombo, 5790, CEP: 87020-900, Maringá, PR, Brazil.

${ }^{2}$ Universidade Estadual de Maringá, Núcleo de Pesquisa em Ictiologia, Limnologia e Aquicultura, Av. Colombo, 5790,
\end{abstract} \\ CEP: 87020-900, Maringá, PR, Brazil. \\ E-mail: taisemlopes@gmail.com (*corresponding author), oscar_pelaez@hotmail.es, rmdias2003@yahoo.com.br, \\ anielly_oliveira@hotmail.com, rafaelagrauber@outlook.com, gomes.luizcarlos@gmail.com, agostinhoaa@gmail.com
}

\begin{abstract}
Body size is a trait that results from evolutionary and ecological processes. Body size not only provides information on the physical condition of individuals but also on the shift in community structure across space and time. Here, we aimed to investigate whether the body size of the migratory fishes changed over time and to ascertain the abiotic variables explaining these changes; and whether the effect on body size was different between fish in dammed (Paraná River) and undammed (Ivinhema River) rivers. Using a temporal series (1986 - 2018) and linear mixed effects models, we evaluated the effects of the abiotic variables on the standard length of the fish species from a floodplain system. We found that fish body size tended to decrease; the mean body length had decreased by $25 \%$ since 2000 . Abiotic variables related to seasonal variability (water level) and those affected by reservoir operation (water transparency and nutrients) explained the decrease in body size. Our results highlighted that larger migratory fish were found in the undammed river in lower transparency habitats.
\end{abstract}

Keywords: flood regime; growth; hydroelectric dam; ichthyology; potamodromous.

\section{INTRODUCTION}

The dams resulting from the installation of hydroelectric power plants to meet the increasing demand for electricity generate many impacts at the local, regional and basin scales (Agostinho et al. 2007a, Winemiller et al. 2016); currently, they are among the main threats to freshwater biodiversity (Rahel 2007). The most noticeable and robust effect is the disruption of river longitudinal connectivity and changes in environmental conditions (Thorton et al. 1990, Ward \& Stanford
1995), with impacts appearing both upstream and downstream (Agostinho et al. 2008). The upstream impacts are mainly due to population fragmentation, the introduction of exotic species, and changes from the lotic to lentic environments in the reservoir region (Agostinho et al. 2007a, Agostinho et al. 2008). The downstream impacts include changes in the hydrological regime, the environmental physicochemical characteristics, productivity dynamics, structure and functioning of assemblages (Agostinho et al. 2004a, Agostinho et al. 2007b, Olden et al. 2010, Wohl et al. 2015, Santos 
et al. 2018) and can be even higher when dams are built upstream of floodplains (Kingsford 2000).

The thermal regime of rivers and flood seasonality play an important role in the health of aquatic ecosystems, directly influencing the distribution and life cycle of species (Ebersole $e t$ al. 2001, Caissie 2006). Water warming can have an effect on freshwater fish metabolism and up to an optimal limit has a positive effect on species behavior, especially in temperate regions (Brett 1971, Biro et al. 2006, Farrell et al. 2009, Dibble et al. 2018). However, if the temperature exceeds the thermal optimum, unless fish can compensate with higher food intake or reallocation of caloric resources, the increased metabolism associated with water warming will reduce their growth rates (Jobling 1997, Biro et al. 2006), causing decreases in the body lengths of fishes (Daufresne et al. 2009, Sheridan \& Bickford 2011). In addition, water warming also plays an important role in fish reproduction, as along with the increase in the photoperiod, water warming is a trigger for gonadal development and maturation in some species (Vazzoler 1996). Physicochemical changes in the river may also alter the spawning and survival patterns of offspring in the early stages of development (Ficke et al. 2007), decreasing the number of adults in the population, which has an indirect effect on fish size. Body size is related to several ecological processes, such as population dynamics, community structure and function, and ecosystem fluxes and exerts strong control on the biomass in the trophic cascade (DeLong et al. 2015). The change in the productivity dynamics caused by the retention of nutrients in reservoirs leads to an increase in water transparency, reducing the nutrient availability and affecting river trophic webs (Hoeinghaus et al. 2008). Nutrient retention also has an effect on fish growth (Gomes \& Agostinho 1997), either indirectly by disrupting interactions and simplifying food webs (Cross et al. 2013) or by reducing food resources for detritivorous fish (Magalhães et al. 2017, Santos et al. 2017).

In river floodplain systems, migratory fishes are directly affected by the downstream effects of dams, mainly due to flow control and the disruption of migration routes (Agostinho et al. 2007a, Antônio et al. 2007, Pelicice et al. 2015). Migratory fish species are generally medium or large in body size and often have roles as top predators and are fundamental to food web structure, nutrient transportation and cycling (Winemiller \& Jepsen 1998). Moreover, migratory species have high social and economic relevance, both for artisanal and sport fishing (Lima 1986, Mateus et al. 2004, Hoeinghaus et al. 2009). Thus, the impacts of dams on their life cycles (Oliveira et al. 2015, Angulo-Valencia et al. 2016) and overfishing are the main threats to these species (Allan et al. 2005, Hoeinghaus et al. 2009).

Body size is a trait that results from evolutionary and ecological processes. Body size not only provides information on the physical condition of individuals but also on the shift in community structure across space and time (Guinot \& Cavin 2018, Villar \& Naya 2018). Thus, the diminished body sizes of migratory species, which are the most economically valuable species, can have an impact on fisheries resources and other human activities, mainly in ecosystem functioning (Oliveira et al. 2018). However, shortterm studies in environments that have frequent perturbations, such as flood pulses, cannot be sensitive to changes in the body size trends. For this reason, long-term studies can offer more accurate data that encompasses a great variety of environmental conditions and the consequent responses of assemblage (Lindemayer et al. 2012). The long-term research conducted on the upper Paraná River floodplain (LTER - Site 6), which is a diverse environment fed by both rivers dammed by upstream hydroelectric dams and by undammed rivers, allows studies such as this to be carried out.

In this context, the main objective of this study was to evaluate the long-term impacts of temperature, flow regulation, and sediment retention from hydroelectric dam construction on migratory fish body size in the upper Paraná River floodplain and whether the effect on body size was different between fish in dammed (Paraná River) and undammed (Ivinhema River) rivers. We hypothesized that fish body size decreased after the closure of the dam and that migratory fish would be smaller in the dammed river than in the undammed river. We expected that the increasing temperature and sediment retention and reduced flooding due to hydroelectric dam construction would negatively affect the body size of migratory fish. 


\section{MATERIAL AND METHODS}

\section{Study area}

The upper Paraná River basin comprises the largest rivers in midwestern and southern Brazil and also has the most dams in South America. The remaining protected floodplain of this basin is situated between the Engenheiro Sérgio Motta hydroelectric dam (built in 1998) and the Binacional Itaipu hydroelectric dam (built in 1982) (Figure 1). The floodplain extends over a $230-\mathrm{km}$ stretch of the Paraná River and plays a fundamental role in the maintenance of fish populations and regional aquatic biological diversity (Agostinho et al. 2001, Agostinho et al. 2008). Situated in the western margin of the Paraná River, the floodplain includes a high diversity of habitats, with ample flooded areas, islands, lakes, canals, and two major tributaries, namely, the Ivinhema and Baia Rivers (Agostinho et al. 2000). The Paraná River is regulated by a cascade of dams upstream but receives inflow from large tributaries and still has marked variations in water level, although without the same intensity and frequency as before the dams were built (Gubiani et al. 2007). The Ivinhema River does not have hydroelectric dam; however, it experiences indirect effects from the regulation of the dams in the Paraná River.

\section{Sampling}

Fish and abiotic variables were sampled before and after the construction of the Engenheiro Sérgio Motta hydroelectric dam (Porto Primavera dam). The before period extended from 1986-1988 and from 1992-1995, with monthly sampling at 12 sites. The after period was from 2000-2018, with quarterly sampling at 12 sites, except in 2000 and 2010, when there were 36 sites.

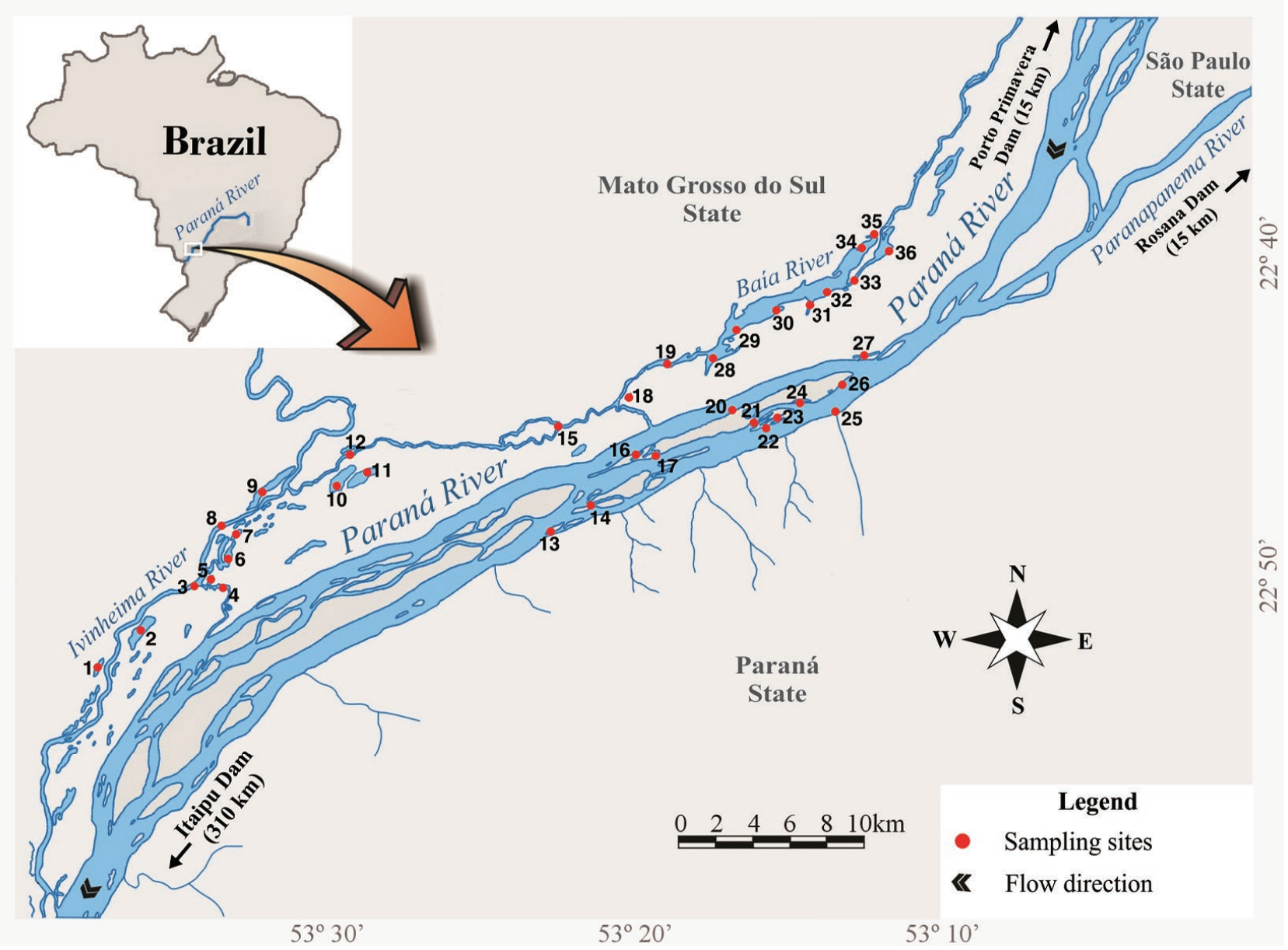

Figure 1. Study area, which includes 36 sampling sites on the Ivinhema (undammed) and Parana (dammed) rivers, during the temporal series. 
Fishes were collected using 10 gillnets of different mesh sizes (3-16 $\mathrm{cm}$ between opposite knots on $20 \mathrm{~m}$ long nets) for both periods. The nets were deployed for $24 \mathrm{~h}$ and checked at 22:00 h, 8:00 h, 16:00 $\mathrm{h}$. The captured fish were anaesthetized with $5 \%$ benzocaine and killed. Each fish was identified based on specialized literature, the standard length was recorded (SL; $\mathrm{cm}$ ), and the stage of gonadal maturation was determined (Vazzoler 1996, BrownPeterson et al. 2011).

We considered only adult fishes that presented gonads in the stages of maturation, which were initial maturation, maturation, mature, semidepleted, depleted, and recovering. The remaining fishes were removed from the sample to avoid confusion between the juvenile and adult stages as the first resting stage occurs before the maturation period (Suzuki H. - personal communication).

The water from the subsurface layer was collected with a van Dorn bottle from a point in the pelagic zone. With digital potentiometers, the physicochemical variables were measured, including the water temperature $\left({ }^{\circ} \mathrm{C}\right)$ and water electrical conductivity $\left(\mu \mathrm{S} . \mathrm{cm}^{-1}\right)$, and the water transparency (m) was measured with a Secchi disc. For analysis of the productivity variables, which included the concentrations of chlorophyll-a ( $\mu \mathrm{g} .1$ $\left.{ }^{1}\right)$, total nitrogen $\left(\mu \mathrm{g} . \mathrm{l}^{-1}\right)$, and total phosphorus $\left(\mu \mathrm{g} . \mathrm{l}^{-}\right.$ $\left.{ }^{1}\right)$, water samples were obtained and preserved on ice. Subsequently, these samples were processed at the Nupelia Basic Limnology Laboratory of State University of Maringá, according to the methodology presented by Golterman et al. (1969) for the estimation of the phytoplankton biomass (chlorophyll-a) and according to Mackereth et al. (1978) for the nutrients. During the before period, the variables were sampled only in rivers (Baia, Ivinhema and Paraná), and during the after period, these variables were sampled in all sites (lakes and rivers - Figure 1). The samples were standardized on an average for the entire months when the fishes were collected.

Hydrologic data were provided by the National Water Agency (Agência Nacional das Águas - ANA; Sistema Nacional de Informações Sobre Recursos Hídricos - SNIRH) and were obtained through daily water level (WL; $\mathrm{cm}$ in relation to the location of a hydrometric station at $231.8 \mathrm{~m}$ a.s.l.) readings at the gauging station on the Paraná River (Porto São José hydrometric station; registration number
64575000) and in the Ivinhema River (Fazenda Ipacaraí hydrometric station; registration number 64614000). The time series for this variable was composed of the arithmetic mean of the daily WL for the entire months when the fishes were collected.

\section{Data analysis}

The possible patterns in the abiotic variables in the undammed and dammed rivers were summarized using principal component analysis (PCA) with normalized data. We used the broken stick model criteria for principal component selection and retained for interpretation the abiotic variables that had correlations greater than 0.70 (eigenvectors) (Jackson 1993).

As we were interested in the temporal trend of body size of migratory fish, the analyses only considered adult individuals of the thirteen most abundant migratory fish (Table 1). We calculated quantiles for the individual bodylengths (standard length) within each sampling campaign. First, a Welch's ANOVA (Moder 2007) was carried out to test whether fish body size differed among the sampling periods: before (1987-1995) and after (2000-2018) the closure of the Engenheiro Sérgio Motta reservoir. Welch's ANOVA was chosen due to the heterogeneity in the variance of the body length.

Then, linear mixed-effects models, in which sampling campaign was a random variable and the data had a Gaussian distribution (identity link function), were fitted to investigate the effect of abiotic variables (water temperature, water electrical conductivity, water transparency, chlorophyll-a, total nitrogen, total phosphorus and water level) on the temporal trend of each standardlength quantile. As multiple sites were sampled and the data collected during each campaign and the fish body size could vary among the sites and during the different sampling, the sampling campaigns were considered random variables. Additionally, when the response variables are not normally distributed, the log-Gaussian models allow the log-transformation of the response to be internalized by exponentiation of the explanatory variable and then linearization of the relationship with body length; this transformation reduces the difficulty of interpreting the log-transformed response variables (Hardin \& Hilbe 2018). As water 
temperature covaries with time (seasonal and long-term trends) and floods may vary with the river water level, the effect of this interaction terms was considered in the models. The best models were selected using the delta Akaike information criterion (AIC), i.e., the models with the lowest delta AIC values were retained for the interpretation (Burnham \& Anderson 2002). Then, the nonlinear effects of the abiotic variables with higher coefficients on body size and their interactions with time were modeled using generalized additive models; sampling campaign identity was again used as a random variable. The analysis were performed in the R platform (R Core Team 2019). The PCA was performed using the package "ade4" (Dray \& Dufour 2007), and the Welch's ANOVA using the package "car" (Fox \& Weisberg 2019). The linear mixed effect models were fitted using the package "lme4" (Bates et al. 2015) and also "car", and generalized additive models using the package "mgcv" (Wood et al. 2016).

\section{RESULTS}

The two first axes of the PCA explained $57.01 \%$ of the variation in the considered abiotic variables (Figure 2). The water transparency $(r=-0.83)$, total phosphorus $(r=0.79)$ and water level $(r=0.75)$ were the main drivers of environmental variability (axis 1). The second axis mainly captured the temporal variation in the water temperature $(r=0.70)$ within each river. Then, the sampled rivers differed from each other, with the Paraná River showing higher water transparency $(2.05 \pm 0.80 \mathrm{~m}$ vs $0.62 \pm 0.30 \mathrm{~m})$ and lower total phosphorus concentration $(24.01 \pm$ $14.18 \mu \mathrm{g} . \mathrm{l}^{-1}$ vs $\left.55.02 \pm 17.55 \mu \mathrm{g} . \mathrm{l}^{-1}\right)$.

Overall, there was a significant decrease in the body size of migratory fish over time from 1987 to 2010. Welch's ANOVA showed that the average body length was $25 \%$ lower after 2000 (mean from 1987$1995=34.5 \mathrm{~cm}$; mean from $2000-2018=25.4 \mathrm{~cm} ; \mathrm{F}$ $=2.104, \mathrm{~N}=10.721, \mathrm{df}=1, \mathrm{p}<0.001)$. After model selection, the water level, year and nutrients were the main explanatory variables explaining the fish body size (Table 2). Thus, the decrease in body size appeared to be mainly associated with a negative effect of water transparency on the $50 \%$ and 75 $\%$ quantiles (15.4 - $65.0 \mathrm{~cm}$ standard length). The water level and phosphorus concentration showed a positive effect on the large organisms (25.2 - 109.6 $\mathrm{cm}$ ), but the water level was only significant for the undammed river (Figure 3a). The nonlinear interactions of the time and abiotic variables (Figure $3 \mathrm{~b})$ showed that larger individuals were captured mainly before 2010 except when the habitats had higher water transparency and lower water levels.

Table 1. Mean and standard deviation of the standardized length of the migratory fishes in the Ivinhema (undammed) and Paraná (dammed) rivers of the upper Paraná River floodplain ( $\mathrm{N}=$ number of individuals).

\begin{tabular}{lcccc}
\hline \multirow{2}{*}{ Species } & \multicolumn{2}{c}{ Ivinhema } & \multicolumn{2}{c}{ Paraná } \\
\cline { 2 - 5 } & Mean $\pm \mathbf{s d}$ & $\mathbf{N}$ & Mean $\pm \mathbf{s d}$ & $\mathbf{N}$ \\
\hline Brycon orbignyanus & $20.54 \pm 7.99$ & 121 & $27.35 \pm 6.50$ & 29 \\
Hemisorubim platyrhynchos & $28.06 \pm 7.20$ & 626 & $26.37 \pm 6.25$ & 26 \\
Megaleporinus obtusidens & $25.73 \pm 7.53$ & 63 & $21.93 \pm 5.50$ & 126 \\
Megaleporinus piavussu & $22.49 \pm 5.54$ & 347 & $23.62 \pm 6.03$ & 135 \\
Piaractus mesopotamicus & $25.37 \pm 7.33$ & 172 & $21.85 \pm 7.22$ & 19 \\
Pinirampus pirinampu & $46.19 \pm 7.77$ & 45 & $47.76 \pm 10.77$ & 5 \\
Prochilodus lineatus & $22.4 \pm 5.60$ & 3838 & $20.6 \pm 5.08$ & 1597 \\
Pseudoplatystoma corruscans & $40.96 \pm 16.73$ & 370 & $41.87 \pm 13.63$ & 72 \\
Pterodoras granulosus & $25.8 \pm 6.89$ & 427 & $36.47 \pm 7.77$ & 83 \\
Rhaphiodon vulpinus & $38.12 \pm 4.73$ & 923 & $36.98 \pm 4.97$ & 666 \\
Rhinelepis aspera & $30.2 \pm 3.14$ & 112 & $29.14 \pm 3.82$ & 295 \\
Salminus brasiliensis & $36.68 \pm 9.56$ & 221 & $32.86 \pm 11.26$ & 79 \\
Salminus hilarii & $21.79 \pm 3.1$ & 81 & $20.44 \pm 3.23$ & 17 \\
Sorubim lima & $28.68 \pm 8.0$ & 148 & $31.26 \pm 7.14$ & 78 \\
\hline
\end{tabular}




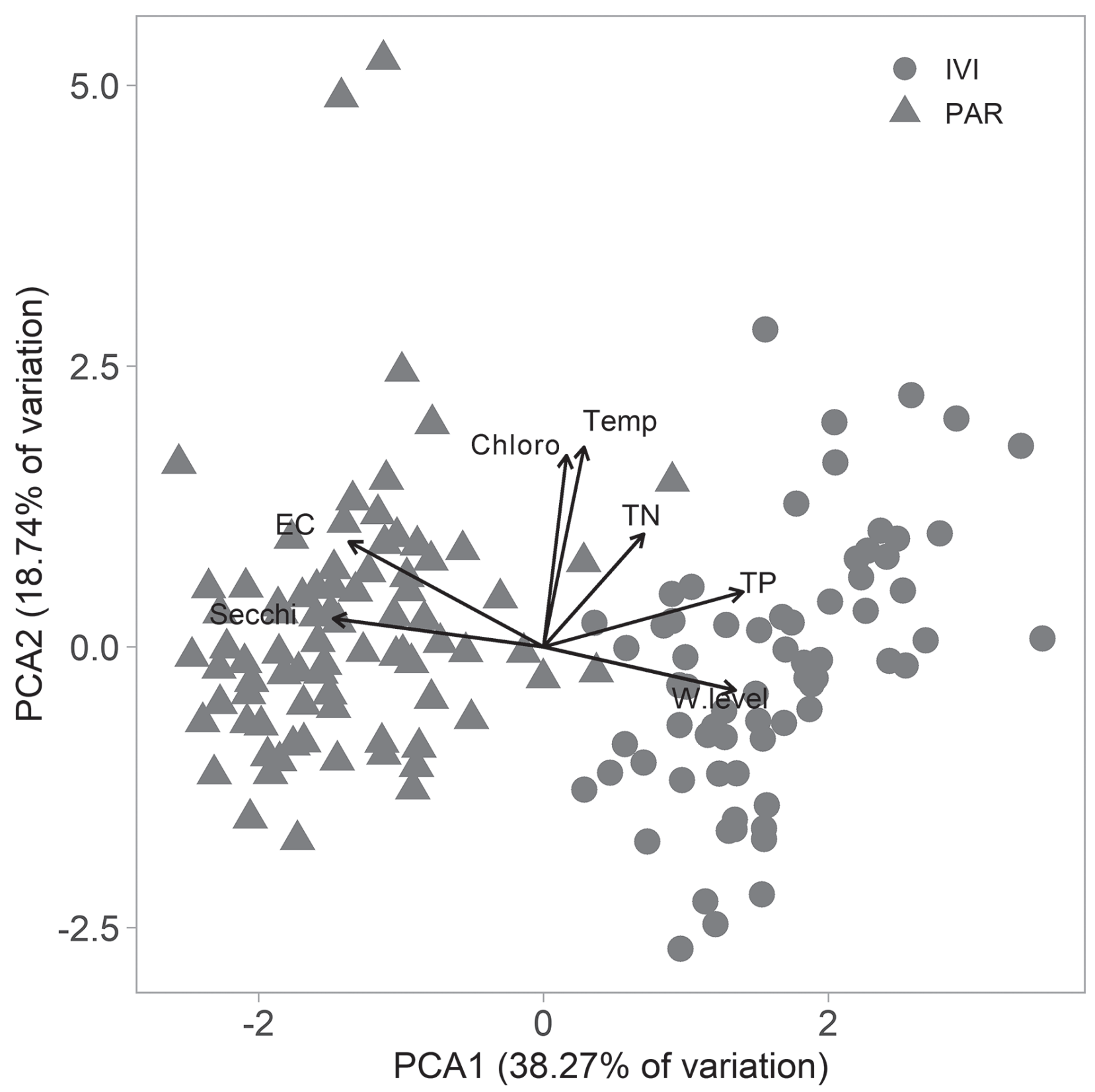

Figure 2. Ordination results from the principal coordinates analysis, indicating the differences in the abiotic variables between the Ivinhema (IVI) and Paraná (PAR) rivers. EC = electrical conductivity; Temp = temperature; $\mathrm{TN}$ = total nitrogen; $\mathrm{TP}=$ total phosphorus; Transp = transparency; $\mathrm{W} \cdot$ level $=$ water level.

For example, the individuals with standard lengths greater than $50 \mathrm{~cm}$ were captured when the water levels exceeded $400 \mathrm{~cm}$. Thus, larger sizes of migratory fish were found in the undammed, lower transparency habitats $(\mathrm{F}=47.62, \mathrm{~N}=147, \mathrm{df}=1, \mathrm{p}<$ 0.001; Figure 4).

\section{DISCUSSION}

The body size of the migratory fish decreased in the Neotropical floodplain after hydroelectric dam construction, with a greater effect on the fish in the dammed river. There was a sharp decline until 2010, with an increase in body size during the following years, which was more distinct in the undammed river. The low water levels and higher transparency were the abiotic variables that are related to this decrease in body size, and the temperature exhibited the opposite expected result. Therefore, the hypotheses of this study were partially corroborated.

The decrease in migratory body size was related 
Table 2. Summary of the Akaike information criterion (AIC) results for the models relating fish body length, time and abiotic variables. $\mathrm{T}=$ water temperature; $\mathrm{WL}=$ water level; Transp = water transparency; $\mathrm{TN}=$ total nitrogen; TP = total phosphorus; Q1 = First quantile (25\%); Q2 = Second quantile (median, 50\%); Q3 = Third quantile (Mean); Q4 = Fourth quantile (75\%); Q5 = Fifth quantile (Maximum values of standard length). The most informative models according to the $\triangle \mathrm{AIC}$ are in bold. Models with $\triangle \mathrm{AIC}$ between $0-2$ have higher support. $\mathrm{DF}=$ degrees of freedom. Weight $=$ the weight of evidence for each model using the Akaike weights.

\begin{tabular}{|c|c|c|c|c|}
\hline & Model & DF & $\Delta \mathrm{AIC}$ & Weight \\
\hline \multirow{7}{*}{ Q1 } & Year + WL:River & 5 & $\mathbf{0}$ & 0.52 \\
\hline & Year + Transp + River & 6 & 1.4 & 0.26 \\
\hline & Year + Transp + River + Year:Transp & 7 & 2.6 & 0.14 \\
\hline & Year + Transp + River + TP+ Year:Transp & 8 & 3.7 & 0.08 \\
\hline & Year $+\mathrm{T}+$ Transp $+\mathrm{WL}+$ River $+\mathrm{TP}+$ & & & \\
\hline & TN + Year:T + Year:Transp + WL:River & 13 & 11.6 & 0.02 \\
\hline & Year + T:Year + Transp:Year + WL:River + Chl + TP+ TN & 14 & 13.5 & 0 \\
\hline \multirow{6}{*}{ Q2 } & Year + T:Year & 5 & $\mathbf{0}$ & 0.40 \\
\hline & Year $+\mathbf{T}+\mathbf{T P}$ & 6 & 1.2 & 0.22 \\
\hline & Year $+T+$ Transp $+\mathbf{T P}$ & 7 & 1.2 & 0.21 \\
\hline & Year $+\mathrm{T}+$ Transp $+\mathrm{TP}+$ Year: $\mathrm{T}$ & 8 & 2.3 & 0.12 \\
\hline & Year $+\mathrm{T}+$ Transp + River $+\mathrm{TP}+$ Year:T +Year:Transp & 10 & 4.5 & 0.4 \\
\hline & Year + T:Year + Transp:Year + WL:River + Chl + TP+ TN & 14 & 10.8 & 0 \\
\hline \multirow{6}{*}{ Q3 } & Year $+\mathrm{T}+$ Transp $+\mathrm{TP}+\mathrm{TN}$ & 8 & $\mathbf{0}$ & 0.41 \\
\hline & Year + T + Transp + TP+ TN + Year:Transp & 9 & 0.4 & 0.34 \\
\hline & Year + T + Transp + TP+ TN + Year:T +Year:Transp & 10 & 1.6 & 0.19 \\
\hline & Year + T + Transp + River + cloro_scl + TP+TN + Year:T + Year:Transp & 12 & 4.8 & 0.04 \\
\hline & $\begin{array}{l}\text { Year }+\mathrm{T}+\text { Transp }+ \text { River }+\mathrm{TP}+\text { Year:T }+ \\
\text { Year:Transp }\end{array}$ & 13 & 6.7 & 0.01 \\
\hline & Year + T:Year + Transp:Year + WL:River + Chl + TP+ TN & 14 & 8.2 & 0 \\
\hline \multirow{6}{*}{ Q4 } & Year $+\mathbf{T}+\mathrm{WL}+\mathbf{T N}$ & 7 & $\mathbf{0}$ & 0.39 \\
\hline & Year $+\mathrm{T}+$ Transp $+\mathrm{WL}+\mathrm{TN}$ & 8 & 0.1 & 0.37 \\
\hline & Year + T + Transp + WL + River + TN + Year:Transp & 10 & 1.9 & 0.15 \\
\hline & Year + T + Transp + WL + River + TN +Year:T + Year:Transp & 11 & 3.6 & 0.06 \\
\hline & Year + T + Transp + WL + River + cloro_scl +TN + Year:T + Year:Transp & 12 & 5.3 & 0.3 \\
\hline & Year + T:Year + Transp:Year + WL:River + Chl + TP+ TN & 14 & 9.2 & 0 \\
\hline \multirow{6}{*}{ Q5 } & Year + T + WL + River + Year:T +WL:River & 9 & $\mathbf{0}$ & 0.40 \\
\hline & Year + T + WL + River + TP + Year:T +WL:River & 10 & 0.2 & 0.37 \\
\hline & Year + T + Transp + WL + River + TP+Year:T + WL:River & 11 & 2.1 & 0.14 \\
\hline & Year + T + Transp + WL + River + TP+Year:T + Year:Transp + WL:River & 12 & 3.9 & 0.06 \\
\hline & Year $+\mathrm{T}+$ Transp $+\mathrm{WL}+$ River $+\mathrm{TP}+\mathrm{TN}+$ Year:T + Year:Transp + WL:River & 13 & 5.9 & 0.02 \\
\hline & Year + T:Year + Transp:Year + WL:River + Chl + TP+ TN & 14 & 7.9 & 0.01 \\
\hline
\end{tabular}


a)
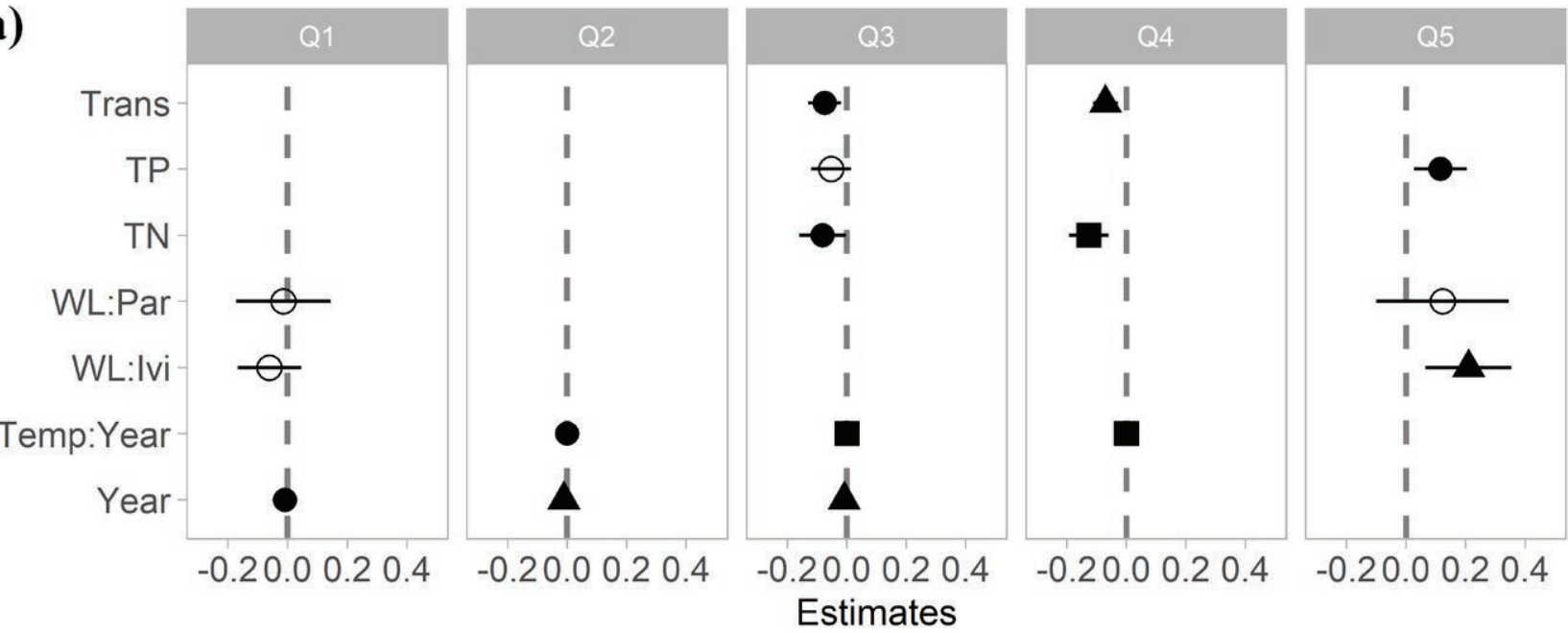

$\bigcirc$ n.s.

b)
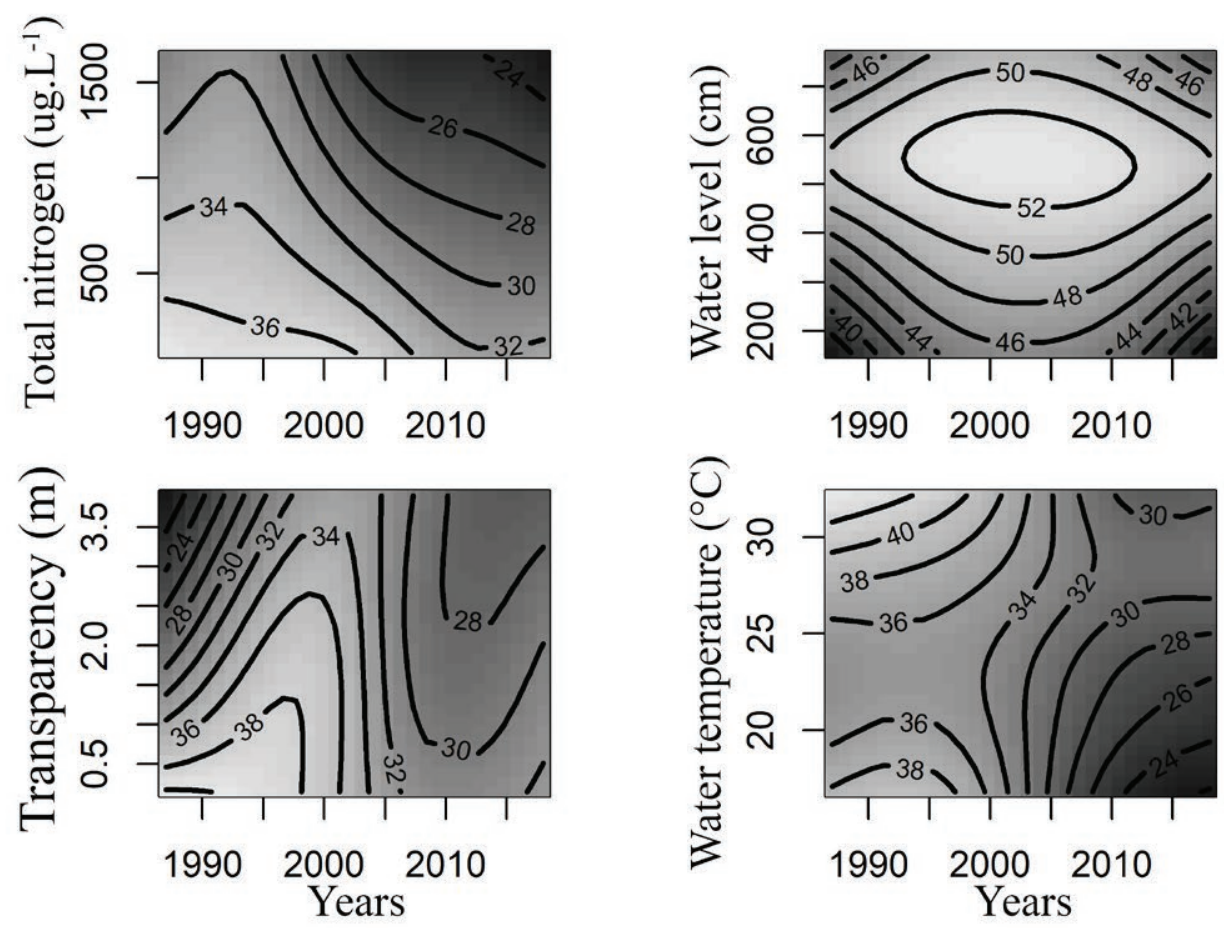

Figure 3. Effects of abiotic variables on the standard length. a) coefficients; $95 \%$ confidence interval and p-values for the mixed linear effects models. Trans: water transparency; $\mathrm{TP}=$ total phosphorus; $\mathrm{TN}=$ total nitrogen; $\mathrm{WL}=$ water level; Temp = water temperature. $\mathrm{b}$ ) Effects on the standard length $(\mathrm{cm})$ of the interaction of the main abiotic variables and time. Light colors for larger standard-length values. Q1 $=$ First quantile (25\%); Q2 = Second quantile (median, $50 \%$ ); Q3 = Third quantile (Mean); Q4 = Fourth quantile (75 \%); Q5 = Fifth quantile (Maximum values of standard length).

to alterations in hydrological regimes. These regimes are naturally controlled by the intensity of precipitation in the upper section of the basin (Comunello et al. 2003, Agostinho et al. 2004c). However, the Paraná River hydrological regime is influenced by the hydroelectric dams that regulate river to meet the energy generation demands (Souza Filho 2009). The regulation imposed by the dams reduced the seasonal fluctuations in the river level and postponed and, in some cases, neutralized the flood peaks (Agostinho et al. 2007a). The absence of flooding also influences the recruitment of migratory fish, reducing the population size in subsequent years (Welcomme 1979, Agostinho et al. 2004b, Oliveira et al. 2015). In addition, the floods inundate vegetated areas and connect 

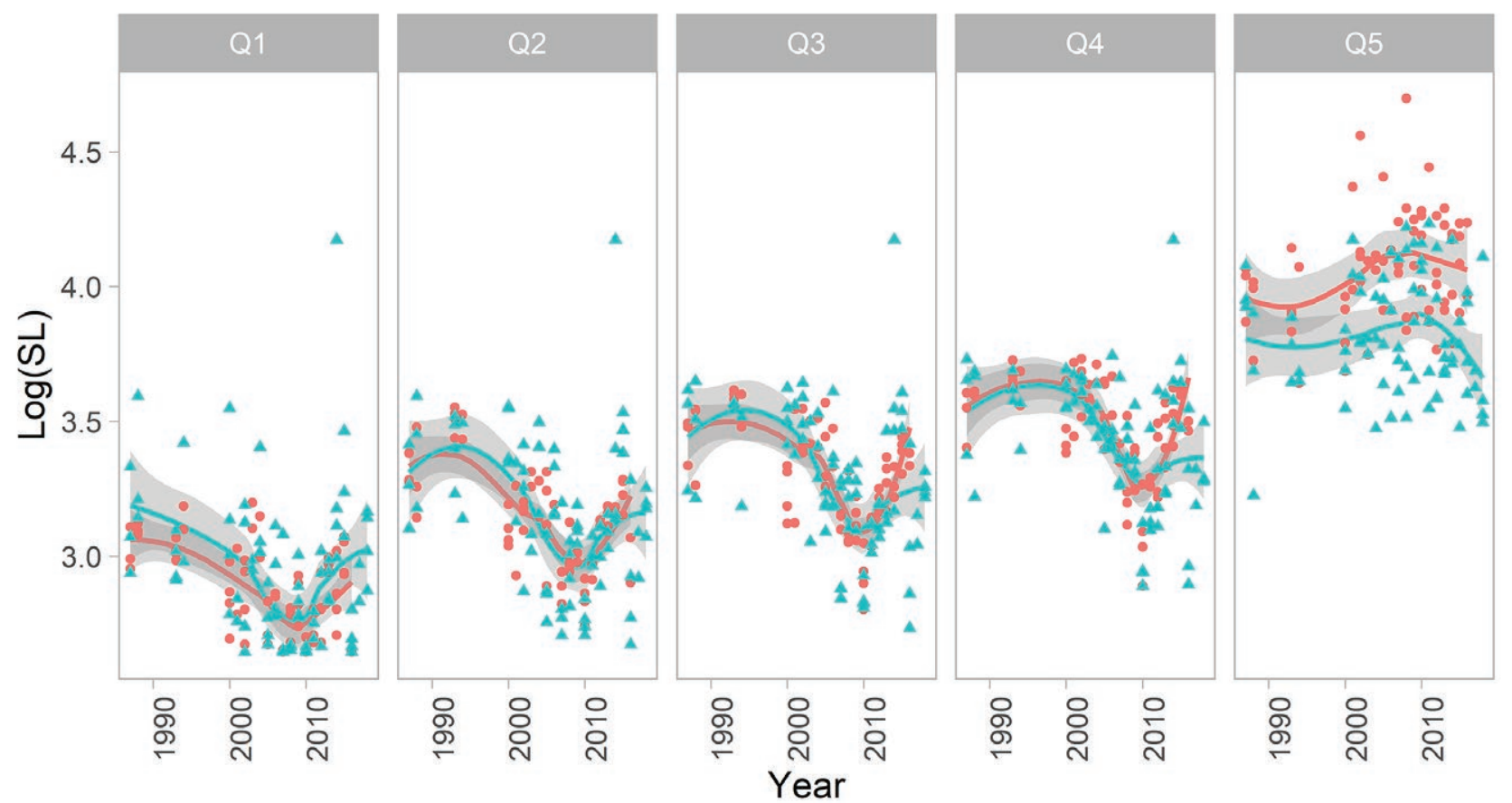

IVI

PAR

Figure 4. Temporal trend in the fish body length in the Ivinhema (IVI - undammed) and Paraná (PAR - dammed) rivers. Q1 = First quantile (25\%); Q2 = Second quantile (median, $50 \%$ ); Q3 = Third quantile (Mean); Q4 = Fourth quantile (75 \%); Q5 = Fifth quantile (Maximum values of standard length).

isolated water bodies, creating favorable conditions for shelter and increasing the availability of food for the alevins and juveniles of migratory fishes (Fisk et al. 2013). Thus, variation in the intensity and duration of floods affects food availability and consequently the nutritional condition (Abujanra et al. 2009) and growth of the juveniles and has a synergistic effect with predation related to the size and natural mortality rates (Gomes \& Agostinho 1997). That is, fewer individuals reach large body sizes, leading to a decrease in the body length in the population over time. Previous studies that assessed the trait diversity showed that the fish communities in the surveyed region had suffered a loss of functional traits related to the migratory species (largest maximum length values, longdistance reproductive migrations and use of pelagic habitats) (Oliveira et al. 2018). These changes in trait diversity were related to the operation of the upstream hydroelectric dam and the alteration of the hydrological cycle (Baumgartner et al. 2018).

The reservoir cascade retains some of the sediment suspended in the water and has increased the river transparency over the years (Roberto et al. 2009, Santos et al. 2017). The lack of nutrients is detrimental for food webs and has severe impacts on primary productivity and the trophic status, since turbidity plays an essential role in predatorprey interactions, diminishing the predation risk (Turesson \& Brönmark 2007, Santos et al. 2018). Consequently, in more transparent waters where all ontogenetic phases of fish can be predated, fewer individuals can reach large sizes. This abiotic change associated with the blockage of migratory routes (Antônio et al. 2007) may be responsible for the sharp decrease in the size of migratory fish, which eventually began to avoid the Paraná River during migration.

The increase in temperature observed in the 19year time series can be attributed to a synergistic effect between the reservoir cascade and the predicted climate warming. Studies have shown future impacts of climate change on the freshwater fish distribution in the tropical regions (Lopes et al. 2017, Ruaro et al. 2019), and decreased body size has been considered the third response to global warming (Gardner et al. 2011). In contrast with what we expected, the water temperature positively influenced the migratory fish body size over time. In our results, the temperature showed 
a slightly positive effect on body size and likely captured the seasonal variation more than the long-term increase in temperature. Both effects (increase and decrease in body size) have already been reported in the literature for different groups of organism, with positive relationships for mammals (Ozgul et al. 2010), but for the fish species in temperate latitudes a consistent pattern of reduction in body size has been found $(10 \%$ 44 \%; Daufresne et al. 2009, Sheridan \& Bickford 2011, Tu et al. 2018. For potamodromous migratory fish in the Neotropical region, water temperature is an important trigger for the reproductive cycle, stimulating the onset of adult gonad maturation, which is completed during the migration to spawning sites (Bailly et al. 2008, Suzuki et al. 2009). The negative effects of river damming likely surpass the effects of the increase in mean temperature, and the effects on body size can take longer to become apparent than those in smaller species, which are more sensitive to temperature changes due to constraints from metabolic allometries (Gillooly et al. 2001). We emphasize the idea that a positive effect can be found until the temperature value that characterizes the optimal limit of physiology is reached, and higher values can affect several biological factors and can even be lethal.

The influence of temperature can be seen to change the dynamics of ecological systems at almost every level, from the physiology of organisms to the rates of ecosystem fluxes (Riemer et al.2018). Since temperature influences the metabolic rate and size during the juvenile stage via growth and development rates (Dabrowski 1986, Sumaila et al. 2011), if the temperature continues to rise at the same rates, the future thermal conditions on the floodplain may become detrimental for fish species (Hopkins et al. 2011, Cheung et al. 2013). Moreover, in the dammed rivers, the effects could be even greater for migratory fish because in addition to disrupting the migratory routes, the dams disrupt the routes for reaching climatically suitable areas, changing the geographic distributions of the species (the second universal rule of global warming) (Gardner et al. 2011) in a process known as "niche tracking" (Monahan \& Tingley 2012).

Despite the marked decrease in migratory body size, there was a change in this trend after 2010, and larger individuals began to be sampled on the floodplain. This trend may be related to the large floods during the periods from 2009-2010 and from 2015-1016, which were caused by El Niño (Southern Oscillation - ENSO) (Oliveira et al. 2015), which probably favored the recruitment and maturation to adulthood of the migratory species. The intermediate-length adults (represented here by Q3 and Q4) increased to a higher proportion of the assemblages in the Ivinhema River, which was probably related to the lasting floods that occurred from 2015-2016. Thus, the sequence of intense and lasting floods was important for the reestablishment of the migratory assemblage on this floodplain.

When we analyzed the largest adults in the population (represented here by Q5), the migratory fishes of the Parana River were smaller than those of the Ivinhema River before the Engenheiro Sérgio Motta hydroelectric dam. Three kinds of fisheries were found in the region: commercial, artisanal and recreational (Petrere 1989, 1996). Historically, the main catches comprised migratory species, such as Salminus, Prochilodus, Piaractus and several catfish species (Agostinho et al. 2007b). These species are highly desirable in regional markets, mainly because of their high-quality flesh. However, overfishing and especially dam construction have negatively impacted the populations of these species, and catches have decreased substantially over the years (Agostinho et al. 1999, Petrere et al. 2002, Hoeinghaus et al. 2009). With the Paraná River basin yielding $\approx 30 \%$ of the fisheries production in Brazil (IBGE 2016), we inferred that historical fishing in this region had fostered the removal of the largest migratory fishes from the Paraná River. In addition to the importance of the fisheries for the size structure, Tu et al. (2018) highlighted that fisheries can accentuate the effects of abiotic variables, such as temperature, and can affect the structure of fish stocks. The presence of larger fish in the Ivinhema River demonstrated the importance of permanent preservation areas, such as the "Parque Estadual das Várzeas do Rio Ivinhema" in this river; the large tract of the preserve includes essential areas for the spawning of migratory species and protects the lower portions of the Ivinheima River, which are the main "nurseries" in the undammed segment of the upper Paraná River floodplain. For a keystone like the "dourado" Salminus brasiliensis (Ruaro et al. 2019), the fishery is forbidden until 2026 in 
the Paraná state (Law N. 22/2018) and until 2024 in Mato Grosso do Sul state (Law N. 19789/2018), where the upper Paraná River is located. It will only be possible to see a recovery in population length after this prohibition period through long-term studies.

Our study highlighted that there was a decrease in the body size of the migratory fish, mainly due to changes in the seasonality in the river level and water transparency caused by the Paraná River reservoir cascade. Therefore, measures must be implemented to require hydroelectric dams to allow the river to exhibit patterns of natural variability to support the recruitment of migratory fish and larger individuals, thus enabling ecosystem functioning. Furthermore, future studies should assess whether the changing environmental conditions due to the reservoir cascade on the Paraná River have altered the fish growth rates, considering species identity, and the information gained here may be useful when partitioning the effects of distinct components (such environmental, climatic or fishery) on the fish size structure.

Our conclusion showed LTER is a good research strategy since we could detect these ecological changes as well as patterns and the underlying processes, which would not be possible with a short term- research data. Thus, these studies could subside management actions aiming at biodiversity conservation and the ecosystem services associated with them, demonstrating the necessity to keep long-term ecological studies.

\section{ACKNOWLEDGEMENTS}

The authors acknowledge all NUPÉLIA staff for the several years of work collecting these data. The collections were supported by Financiadora de Estudos e Projetos (FINEP, 1994-1995) and Programa de Apoio ao Desenvolvimento Científico e Tecnológico - subprograma Ciências Ambientais (PADCT/CIAMB, 1986-1988). We also thank the Conselho Nacional de Desenvolvimento Científico e Tecnológico (CNPq) for supporting the LongTerm Ecological Research (Programa de Pesquisas Ecológicas de longa duração - PELD - Sítio 6 "A planície de inundação do alto Rio Paraná”). CNPq was also responsible to support TML and AGO post-doctoral scholarship, OPZ Ph.D scholarship, and AAA for productivity grant and AAA and LCG for continuous support. RMD and RGR thank the Coordenação de Aperfeiçoamento Pessoal de Nível Superior (CAPES) for post-doctoral research and Ph.D scholarship, respectively.

\section{REFERENCES}

Abujanra, F., Agostinho, A., \& Hahn, N. 2009. Effects of the flood regime on the body condition of fish of different trophic guilds in the Upper Paraná River floodplain, Brazil. Brazilian Journal of Biology, 69(2), 469-479. DOI: 10.1590/s151969842009000300003

Agostinho, A. A., Okada, E. K., \& Gregoris, J. 1999. A pesca no reservatório de Itaipu: aspectos socioeconômicos e impactos do represamento. In: R. Henry (Ed.), Ecologia de reservatórios: estrutura, função e aspectos sociais'. pp. 281-319. Botucatu, São Paulo: Instituto de Biociências, UNESP.

Agostinho, A., Pelicice, F., \& Gomes, L. 2008. Dams and the fish fauna of the Neotropical region: impacts and management related to diversity and fisheries. Brazilian Journal of Biology, 68(4), 1119-1132. DOI: 10.1590/S151969842008000500019

Agostinho, A. A., Gomes, L. C., Veríssimo, S., \& Okada, E. K. 2004. Flood regime, dam regulation and fish in the Upper Paraná River: Effects on assemblage attributes, reproduction and recruitment. Reviews in Fish Biology and Fisheries, 14(1), 11-19. DOI: 10.1007/s11160004-3551-y

Agostinho, A. A., Gomes, L. C., \& Pelicice, F. M. 2007a. Ecologia e manejo de recursos pesqueiros em reservatórios do Brasil. Maringá: EDUEM: $p$. 501.

Agostinho, A. A., Gomes, L. C., Thomaz, S. M., \& Hahn, N. S. 2004. The upper Paraná river and its floodplain: Main characteristics and perspectives for management and conservation. In: S. M. Thomaz, A. A. Agostinho, \& N. S. Hahn (Eds.), The upper Paraná river and its floodplain physical aspects, ecology and conservation. pp. 381-393. Backhuys Publishers, Leiden.

Agostinho, A. A., Gomes, L. C., \& Zalewski, M. 2001. The importance of floodplains for the dynamics of fish communities of the upper river Paraná. International Journal of Ecohydrology \& Hydrobiology, 1(1-2), 209-217. 
Agostinho, A. A., Marques, E. E., Agostinho, C. S., Almeida, D. A., Oliveira, R. J., \& Melo, J. R. B.2007b. Fish ladder of Lajeado Dam: Migrations on oneway routes? Neotropical Ichthyology, 5(2), 121130. DOI: 10.1590/S1679-62252007000200005

Agostinho, A. A., Thomaz, S. M., Minte-Vera, C. V., \& Winemiller, K. O. 2000. Biodiversity in the high Paraná River floodplain. In: B. Gopal, W. J. Junk, \& J. A. Davis (Eds.), Biodiversity in wetlands: assessment, function and conservation. 1st ed., pp. 89-118. Leiden, The Netherlands: Backhuys Publishers.

Allan, J. D., Abell, R., Hogan, Z., Revenga, C., Taylor, B. W., Welcomme, R. L., \& Winemiller, K. 2005. Overfishing of Inland Waters. BioScience, 55(12), 1041-1051. DOI:10.1641/00063568(2005)055[1041:OOIW]2.0.CO;2

Angulo-Valencia, M. A., Agostinho, A. A., Suzuki, H. I., da Luz-Agostinho, K. D. G., \& Agostinho, C. S. 2016. Impoundments affect fish reproduction regardless of reproductive strategy. Lakes and Reservoirs: Research and Management, 21(4), 362-374. DOI: 10.1111/lre.12151

Antônio, R. R., Agostinho, A. A., Pelicice, F. M., Bailly, D., Okada, E. K., \& Dias, J. H. P. 2007. Blockage of migration routes by dam construction: Can migratory fish find alternative routes? Neotropical Ichthyology, 5(2), 177-184. DOI: 10.1590/S1679-62252007000200012

Bailly, D., Agostinho, A. A., \& Suzuki, H. I. 2008. Species with different reproductive strategies in the cuiaba river, upper Pantanal brazil. River Research and Applications, 1229(1), 1218-1229.

Baumgartner, M. T., Oliveira, A. G., Agostinho, A. A., \& Gomes, L. C. 2018. Fish functional diversity responses following flood pulses in the upper Paraná River floodplain. Ecology of Freshwater Fish, 27(4), 910-919. DOI: 10.1111/eff.12402

Biro, P. A., Abrahams, M. V., Post, J. R., \& Parkinson, E. A. 2006. Behavioural trade-offs between growth and mortality explain evolution of submaximal growth rates. The Journal of Animal Ecology, 75(5), 1165-1171. DOI: 10.1111/j.13652656.2006.01137.x

Brett, J. R. 1971. Energetic responses of salmon to temperature. A study of some thermal relations in the physiology and freshwater ecology of sockeye salmon (Oncorhynchus nerkd). Integrative and Comparative Biology, 11(1), 99113. DOI: $10.1093 / \mathrm{icb} / 11.1 .99$
Brown-Peterson, N. J., Wyanski, D. M., SaboridoRey, F., Macewicz, B. J., \& Lowerre-Barbieri, S. K. 2011. A Standardized Terminology for Describing Reproductive Development in Fishes. Marine and Coastal Fisheries, 3(1), 5270. doi:10.1080/19425120.2011.555724.

Burnham, K. P., \& Anderson, D. R. 2002. Model selection and multimodel inference: A practical information-theoretic approach. Ecological Modelling. 2nd ed.Springer-Verlag. p. 488.

Caissie, D. 2006. The thermal regime of rivers: A review. Freshwater Biology. 51(8), 1389-1406. DOI: 10.1111/j.1365-2427.2006.01597.x

Cheung, W. W. L., Sarmiento, J. L., Dunne, J., Frölicher, T. L., Lam, V. W. Y., Palomares, M. L. D., Watson, R., \& Pauly, D. 2013. Shrinking of fishes exacerbates impacts of global ocean changes on marine ecosystems. Nature Climate Change, 3(3), 254-258. DOI: 10.1038/nclimate1691

Comunello, E., Sousa Filho, E. E., \& Rocha, P. C. 2003. Dinâmica de inundação de áreas sazonalmente alagáveis na Planície Aluvial do Alto Rio Paraná: Estudo preliminar. In: Anais do $11^{\circ}$ Simpósio brasileiro de sensoriamento remoto. pp. 24592466. São José Dos Campos: Inpe.

Cross, W. F., Baxter, C. V., Rosi-Marshall, E. J., Hall, R. O., Kennedy, T. A., Donner, K. C., Wellard Kelly, H. A., Seegert, S. E. Z., Behn, K. E., \& Yard, M. D. 2013. Food-web dynamics in a large river discontinuum. Ecological Monographs, 83(3), 311-337. DOI: 10.1890/12-1727.1

Dabrowski, K. R. 1986. Ontogenetical aspects of nutritional requirements in fish. Comparative Biochemistry and Physiology -- Part A: Physiology, 85(4), 639-655. DOI: 10.1016/03009629(86)90272-0

Daufresne, M., Lengfellner, K., \& Sommer, U. 2009. Global warming benefits the small in aquatic ecosystems. Proceedings of the National Academy of Sciences of the United States of America, 106(31), 12788-12793. DOI: 10.1073/ pnas.0902080106

DeLong, J. P., Gilbert, B., Shurin, J. B., Savage, V. M., Barton, B. T., Clements, C. F., Dell, A. I., Greig, H. S., Harley, C. D. G., Kratina, P., McCann, K. S., Tunney, T. D., Vasseur, D. A., \& O'Connor, M. I. 2015. The Body Size Dependence of Trophic Cascades. The American Naturalist, 185(3), 354366. DOI: 10.1086/679735

Dibble, K. L., Yackulic, C. B., \& Kennedy, T. A. 
2018. Warm water temperatures and shifts in seasonality increase trout recruitment but only moderately decrease adult size in western North American tailwaters. Environmental Biology of Fishes, 101(8), 1269-1283. DOI: 10.1007/s10641018-0774-7

Dray, S., \& Dufour, A. 2007. The ade4 Package: Implementing the Duality Diagram for Ecologists.Journal of Statistical Software. DOI: 10.18637 /jss.v022.i04

Ebersole, J. L., Liss, W. J., \& Frissell, C. A. 2001. Relationship between stream temperature, thermal refugia and rainbow trout Oncorhynchus mykiss abundance in arid-land streams in the northwestern United States. Ecology of Freshwater Fish, 10, 1-10. DOI: 10.1034/j.1600-0633.2001.100101.x

Farrell, A. P., Eliason, E. J., Sandblom, E., \& Clark, T. D. 2009. Fish cardiorespiratory physiology in an era of climate change. Canadian Journal of Zoology, 87(10), 835-851. DOI: 10.1139/Z09-092

Ficke, A. D., Myrick, C. A., \& Hansen, L. J. 2007. Potential impacts of global climate change on freshwater fisheries. Reviews in Fish Biology and Fisheries, 17(4), 581-613. DOI: 10.1007/s11160007-9059-5

Fisk, J. M., Kwak, T. J., Heise, R. J., \& Sessions, F. W. 2013. Redd Dewatering Effects On Hatching And Larval Survival Of The Robust Redhorse. River Research and Applications, 29(5), 574-581. DOI: 10.1002/rra.2561

Gardner, J. L., Peters, A., Kearney, M. R., Joseph, L., \& Heinsohn, R. 2011. Declining body size: A third universal response to warming? Trends in Ecology and Evolution, 26(6), 285-291. DOI: 10.1016/j.tree.2011.03.005

Gillooly, J. F., Brown, J. H., West, G. B., Savage, V. M., \& Charnov, E. L. 2001. Effects of size and temperature on metabolic rate. Science, 293(5538), 2248-2251. DOI: 10.1126/ science. 1061967

Gomes, L. C., \& Agostinho, A. A. 1997. Influence of the flooding regime on the nutritional state and juvenile recruitment of the curimba, Prochilodus scrofa, Steindachner, in upper Paraná River, Brazil. Fisheries Management and Ecology, 4(4), 263-274. DOI: 10.1046/j.1365-2400.1997.00119.x

Gubiani, É. A., Gomes, L. C., Agostinho, A. A., \& Okada, E. K. 2007. Persistence of fish populations in the upper Paraná River: effects of water regulation by dams. Ecology of Freshwater Fish, 16(2), 191-197. DOI: 10.1111/j.16000633.2006.00211.x

Hardin, J. W., \& Hilbe, J. M. 2018. Generalized linear models and extensions. 4 ed. College Station: Stata Press: p. 598.

Hoeinghaus, D. J., Agostinho, A. A., Gomes, L. C., Pelicice, F. M., Okada, E. K., Latini, J. D., Kashiwaqui, E. A. L., \& Winemiller, K. O. 2009. Effects of river impoundment on ecosystem services of large tropical rivers: Embodied energy and market value of artisanal fisheries. Conservation Biology, 23(5), 1222-1231. DOI: 10.1111/j.1523-1739.2009.01248.x

Hoeinghaus, D. J., Winemiller, K. O., \& Agostinho, A. A. 2008. Hydrogeomorphology and river impoundment affect food-chain length of diverse Neotropical food webs. Oikos, 117(7), 984-995. DOI: 10.1111/j.0030-1299.2008.16459.x

Hopkins, K., Moss, B. R., \& Gill, A. B. 2011. Increased ambient temperature alters the parental care behaviour and reproductive success of the threespined stickleback (Gasterosteus aculeatus). Environmental Biology of Fishes, 90, 121-129. DOI: 10.1007/s10641-010-9724-8

IBGE. 2016. Pesquisa da Pecuária Municipal 2016. p. 51. Rio de Janeiro.

Jobling, M. 1997. Temperature and growth: modulation of growth rates via temperature change. In: Wood, D. G., McDonald, C. M. (Eds.), Global Warming: Implications for Freshwater and Marine Fish. pp. 225-253. Cambridge: Cambridge University Press.

Fox, J., \& Weisberg, S. 2019. An $\{\mathrm{R}\}$ Companion to Applied Regression. 3th ed. Thousand Oaks CA: Sage.

Kingsford, R. T. 2000. Ecological impacts of dams, water diversions and river management on floodplain wetlands in Australia. Austral Ecology, 25(2), 109-127.

Lima, J. A. F. de. 1986. A pesca no pantanal de Mato Grosso (Rio Cuiabá: Importância dos peixes migradores). Acta Amazonica, 16, 87-94. DOI: 10.1590/1809-43921986161094

Lindemayer, D. B., Likens, G. E., Andersen, A., Bowman, D., Bull, C. M., Burns, E., Dickman, C. R., Hoffmann, A. A., Keith, D. A., Liddell, M. J., Lowe, A. J., Metcalfe, D. J., Phinn, S. R., RusselSmith, J., Thurgate, N., \& Wardle, G. M. 2012. Value of long-term ecological studies. Austral 
Ecology, 37(7), 745-757. DOI: 10.1111/j.14429993.2011.02351.x

Lopes, T. M., Bailly, D., Almeida, B. A., Santos, N. C. L., Gimenez, B. C. G., Landgraf, G. O., Sales, P. C. L., Lima-Ribeiro, M. S., Cassemiro, F. A. S., Rangel, T. F., Diniz-Filho, J. A. F., Agostinho, A. A., \& Gomes, L. C. 2017. Two sides of a coin: Effects of climate change on the native and nonnative distribution of Colossoma macropomum in South America. PLoS ONE, 12(6), 1-18. DOI: 10.1371/journal.pone.0179684

Magalhães, A. L. B., Orsi, M. L., Pelicice, F. M., Azevedo-Santos, V. M., Vitule, J. R. S., P. LimaJunior, D., Brito, M. F. G., Magalhães, A. L. B., Orsi, M. L., Pelicice, F. M., Azevedo-Santos, V. M., Vitule, J. R. S., Lima-Junior, D. P., \& Brito, M. F. G. 2017. Small size today, aquarium dumping tomorrow: sales of juvenile non-native large fish as an important threat in Brazil. Neotropical Ichthyology, 15(4). DOI: 10.1590/1982-022420170033

Mateus, L. A. F., Penha, J. M. F., \& Petrere, M. 2004. Fishing resources in the rio Cuiabá basin, Pantanal do Mato Grosso, Brazil. Neotropical Ichthyology, 2(4), 217-227. DOI: 10.1590/S167962252004000400004

Moder, K. 2007. How to keep the Type I Error Rate in ANOVA if Variances are Heteroscedastic. Austrian Journal of Statistics, 36, 179-188.

Monahan, W. B., \& Tingley, M. W. 2012. Niche Tracking and Rapid Establishment of Distributional Equilibrium in the House Sparrow Show Potential Responsiveness of Species to Climate Change. PLoS ONE, 7(7), e42097. DOI: 10.1371/journal.pone.0042097

Olden, J. D., Kennard, M. J., Leprieur, F., Tedesco, P. A., Winemiller, K. O., \& García-Berthou, E. 2010. Conservation biogeography of freshwater fishes: recent progress and future challenges. Diversity and Distributions, 16(3), 496-513. DOI: 10.1111/j.1472-4642.2010.00655.x

Oliveira, A. G., Baumgartner, M. T., Gomes, L. C., Dias, R. M., \& Agostinho, A. A. 2018. Long-term effects of flow regulation by dams simplify fish functional diversity. Freshwater Biology, 63(3), 293-305. DOI: 10.1111/fwb.13064

Oliveira, A. G., Suzuki, H. I., Gomes, L. C., \& Agostinho, A. A. 2015. Interspecific variation in migratory fish recruitment in the Upper Paraná River: Effects of the duration and timing of floods. Environmental Biology of Fishes, 98(5), 1327-1337. DOI: 10.1007/s10641-014-0361-5

Ozgul, A., Childs, D. Z., Oli, M. K., Armitage, K. B., Blumstein, D. T., Olson, L. E., Tuljapurkar, S., \& Coulson, T. 2010. Coupled dynamics of body mass and population growth in response to environmental change. Nature, 466(7305), 482485. DOI: $10.1038 /$ nature 09210

Petrere, M., Agostinho, A. A., Okada, E. K., \& Júlio, H. F. 2002. Review of the Fisheries in the Brazilian Portion of the Paraná/Pantanal Basin. In: I. G. Cowx (Ed.), Management and Ecology of Lake and Reservoir Fisheries. pp. 123-143. Osney Mead: Fishing New Books.

R Core Team. 2019. R: The R Project for Statistical Computing. (Retrieved on June 4th, 2019, from https://www.r-project.org/).

Rahel, F. J. 2007. Biogeographic barriers, connectivity and homogenization of freshwater faunas: It's a small world after all. Freshwater Biology, 52(4), 696-710. DOI: 10.1111/j.1365-2427.2006.01708.x

Riemer, K., Anderson-Teixeira, K. J., Smith, F. A., Harris, D. J., \& Ernest, S. K. M. 2018. Body size shifts influence effects of increasing temperatures on ectotherm metabolism. Global Ecology and Biogeography, 27(8), 958967. DOI: 10.1111/geb.12757

Roberto, M. C., Santana, N. N., \& Thomaz, S. M. 2009. Limnology in the Upper Paraná River floodplain: large-scale spatial and temporal patterns, and the influence of reservoirs. Brazilian Journal of Biology, 69(2), 717-725.

Ruaro, R., Conceição, E. O., Silva, J. C., Cafofo, E. G., Angulo-Valencia, M. A., Mantovano, T., Pineda, A., de Paula, A. C. M., Zanco, B. F., Capparros, E. M., Moresco, G. A., de Oliveira, I. J., Antiqueira, J. L., Ernandes-Silva, J., da Silva, J. V. F., Adelino, J. R. P., dos Santos, J. A., Ganassin, M. J. M., Iquematsu, M. S., Landgraf, G. O., Lemes, P., Cassemiro, F. A. S., BatistaSilva, V. F., Diniz-Filho, J. A. F., Rangel, T. F., Agostinho, A. A., \& Bailly, D. 2019. Climate change will decrease the range of a keystone fish species in La Plata River Basin, South America. Hydrobiologia, 836(1), 1-19. DOI: 10.1007/s10750-019-3904-0

Santos, A. F. G. N., García-Berthou, E., Hayashi, C., \& Santos, L. N. 2018. Water turbidity increases biotic resistance of native Neotropical 
piscivores to alien fish. Hydrobiologia, 817(1), 293-305. DOI: 10.1007/s10750-018-3548-5

Santos, N. C. L., de Santana, H. S., Ortega, J. C. G., Dias, R. M., Stegmann, L. F., da Silva Araújo, I. M., Severi, W., Bini, L. M., Gomes, L. C., \& Agostinho, A. A. 2017. Environmental filters predict the trait composition of fish communities in reservoir cascades. Hydrobiologia, 802(1), 245-253. DOI: 10.1007/s10750-017-3274-4

Sheridan, J. A., \& Bickford, D. 2011. Shrinking body size as an ecological response to climate change. Nature Climate Change, 1(8), 401-406. DOI: $10.1038 /$ nclimate 1259

Souza Filho, E. 2009. Evaluation of the Upper Paraná River discharge controlled by reservoirs. Brazilian Journal of Biology, 69(2), 707-716. DOI: 10.1590/s1519-69842009000300024

Sumaila, U. R., Cheung, W. W. L., Lam, V. W. Y., Pauly, D., \& Herrick, S. 2011. Climate change impacts on the biophysics and economics of world fisheries. Nature Climate Change, 1(9), 449-456. DOI: $10.1038 /$ nclimate1301

Suzuki, H. I., Agostinho, A. A., Bailly, D., Gimenes, M. F., Júlio, H. F., \& Gomes, L. C. 2009. Interannual variations in the abundance of young-ofthe-year of migratory fishes in the Upper Paraná River floodplain: relations with hydrographic attributes. Brazilian Journal of Biology, 69(2), 649-60.

Thorton, K. W., Kimmel, B. L., \& Payne, F. E. 1990. Reservoir limnology: ecological perspectives. New Jersey: John Willey \& Sons: p. 246.

Tu, C. Y., Chen, K. T., \& Hsieh, C. H. 2018. Fishing and temperature effects on the size structure of exploited fish stocks. Scientific Reports, 8(1). DOI: 10.1038/s41598-018-25403-X

Vazzoler, A. E. A. M. 1996. Biologia da reprodução de peixes teleósteos: teoria e prática. Notas de estudo de Ciências Biológicas. Universidade Estadual Paulista - Unesp. p. 171.

Ward, J. V., \& Stanford, J. A. 1995. The serial discontinuity concept: Extending the model to floodplain rivers. Regulated Rivers: Research \& Management. DOI: 10.1002/rrr.3450100211

Welcomme, R. L. 1979. Fisheries ecology of floodplain rivers.Longman: p. 317.

Winemiller, K. O., McIntyre, P. B., Castello, L., FluetChouinard, E., Giarrizzo, T., Nam, S., Baird, I. G., Darwall, W., Lujan, N. K., Harrison, I., Stiassny, M. L. J., Silvano, R. A. M., Fitzgerald,
D. B., Pelicice, F. M., Agostinho, A. A., Gomes, L. C., Albert, J. S., Baran, E., Petrere, M., Zarfl, C., Mulligan, M., Sullivan, J. P., Arantes, C. C., Sousa, L. M., Koning, A. A., Hoeinghaus, D. J., Sabaj, M., Lundberg, J. G., Armbruster, J., Thieme, M. L., Petry, P., Zuanon, J., Vilara, G. T., Snoeks, J., Ou, C., Rainboth, W., Pavanelli, C. S., Akama, A., van Soesbergen, A., \& Saenz, L. 2016. Balancing hydropower and biodiversity in the Amazon, Congo, and Mekong. Science, 351(6269), 128129. DOI: $10.1126 /$ science.aac7082

Wohl, E., Bledsoe, B. P., Jacobson, R. B., Poff, N. L., Rathburn, S. L., Walters, D. M., \& Wilcox, A. C. 2015. The natural sediment regime in rivers: Broadening the foundation for ecosystem management. BioScience, 65(4), 358-371 DOI: 10.1093/biosci/biv002

Wood, S. N., Pya, N., \& Säfken, B. 2016. Smoothing parameter and model selection for general smooth models. Journal of the American Statistical Association, 111(516), 1548-1563. DOI: 10.1080/01621459.2016.1180986

Submitted: 3 September 2019 Accepted: 1 April 2020

Published on line: 15 June 2020 Associate Editors: Camila Barros and Nuria Pistón 
504 | Temporal Changes in Fish Body Size in Floodplain 